\title{
Tetrathionate production by sulfur oxidizing bacteria and the role of tetrathionate in the sulfur cycle of Baltic Sea sediments
}

\author{
Lilijana Podgorsek, Johannes F. Imhoff* \\ Institut für Meereskunde, Abteilung Marine Mikrobiologie, Düsternbrooker Weg 20, D-24105 Kiel, Germany
}

\begin{abstract}
The role of tetrathionate in the sulfur cycle of Baltic Sea sediments was investigated in different habitats and under a variety of environmental conditions. Sediment profiles were recorded with regard to numbers of thiosulfate oxidizing bacteria, concentrations of sulfur compounds, and potential rates of thiosulfate oxidation. Products of thiosulfate oxidation were quantified in incubated sediment samples and in pure cultures. Evidence was found that tetrathionate is formed within these sediments, that sulfur oxidizing bacteria are present in considerable numbers, that these bacteria are of major importance in the oxidation of reduced sulfur compounds in their habitat, and that tetrathionate is an important oxidation product of these bacteria. Thiosulfate is oxidized by bacteria isolated from these sediments to varying proportions of tetrathionate, sulfate, and also elemental sulfur. In highly sulfidic sediments and in the presence of large amounts of organic matter, tetrathionate was present in sediment horizons in which thiosulfate and elemental sulfur also accumulated. A tetrathionate cycle is proposed to be active in natural marine and brackish water sediments in which, due to combined bacterial action and chemical reactions, a net oxidation of sulfide to elemental sulfur occurs in the presence of catalytic amounts of thiosulfate and tetrathionate.
\end{abstract}

KEY WORDS: Tetrathionate - Thiosulfate $\cdot$ Sulfur oxidation - Sulfur oxidizing bacteria $\cdot$ Tetrathionate cycle Baltic Sea

\section{INTRODUCTION}

The roles of sulfate, elemental sulfur and sulfide in biological and geochemical cycles are well characterized (e.g. Jørgensen 1988, Kelly 1988). Thiosulfate has also been recognized as a central intermediate in sulfur cycling of marine sediments (Jørgensen 1990, Jørgensen \& Bak 1991). In recent years an increasing amount of information has been accumulated on bacterial transformations of sulfur compounds of intermediate redox level (elemental sulfur, thiosulfate, sulfite) in oxidative and reductive processes, including reactions of disproportionation (Jørgensen \& Bak 1991, Thamdrup et al. 1993, Vedenina \& Sorokin 1993, Canfield \& Thamdrup 1996, Sorokin et al. 1996). Thiosulfate and trithionate, and to a lesser extent also tetrathionate, have been found as intermediates during sulfate and sulfite reduction by sulfate reducing bacte-

\footnotetext{
- Addressee for correspondence.

E-mail: jimhoff@ifm.uni-kiel.de
}

ria from freshwater and marine sources (Fitz \& Cypionka 1990, Sass et al. 1992). Tetrathionate is also well known as an intermediate in the oxidation of reduced sulfur compounds to sulfate by Thiobacillus tepidarius, Thiobacillus intermedius and other thiobacilli (Wood \& Kelly 1986, Lu \& Kelly 1988, Kuenen et al. 1992 Wentzien et al. 1994). In addition, tetrathionate formation is a property of many chemoheterotrophic bacteria (Tuttle et al. 1974, Mason \& Kelly 1988, Sorokin 1993, 1996, Sorokin et al. 1996).

However, the role of tetrathionate in the sulfur cycle of marine sediments is poorly understood. Although from pure culture studies tetrathionate is known as an oxidation product of thiosulfate in several chemoheterotrophic bacteria from different marine environments (Tuttle et al. 1974, Sorokin 1992, 1993, Durand et al. 1994), the importance of these bacteria in the natural environment has so far not been estimated.

We have found evidence that tetrathionate is formed within the investigated Baltic Sea sediments, that it is an important oxidation product of sulfur oxidizing bac- 
teria isolated from these sediments, and that these bacteria are present in considerable numbers within the sediments. We therefore conclude that tetrathionate plays a significant role within the sulfur cycle of marine and brackish water sediments. Apparently, its formation is favored in highly sulfidic sediments and in the presence of large amounts of organic matter, as indicated by experimental manipulation of the sediments. A preliminary discussion on the role of tetrathionate in the sulfur cycle of marine sediments and on the importance of possible interactions with sulfide to form elemental sulfur and thiosulfate has been presented earlier (Imhoff 1996).

\section{MATERIALS AND METHODS}

Habitats and sampling. The present studies were confined to habitats of the Baltic Sea. The principal part of these investigations was made within sediments of 2 coastal locations. In addition a few supporting experiments and measurements were done in the Gotland Basin.

Hiddensee: One of the locations was at the shore of the 'Fährinsel' close to Hiddensee, Germany (site Hiddensee $\mathrm{K}$ ). An area of approx. $15 \mathrm{~m}^{2}$ was covered with a plastic sheet from June to November 1993 to produce stable anoxic conditions. A comparison between an uncovered control area and the covered area was made in November immediately after removal of the cover sheet.

Bottsand: A second location was at the Bottsand close to Kiel, Germany. It was used to set up an experimental sediment system $(1.20 \times 2.80 \mathrm{~m}$ in size $)$ under controlled conditions in the lab to study the effect of different environmental parameters on processes of the sulfur cycle. Sediment was taken from the environment in layers that were homogenized and reassembled in the experimental system. Temperature, salinity and flow rate of the supernatant water were controlled and together with $\mathrm{pH}$-value and redox potential of the sediment profiles continuously recorded. Four compartments were distinguished by different amounts of natural organic matter (finely ground seaweed and algal matcrialy addod at a depth of 2 to $3 \mathrm{~cm}$ into the sediment. The untreated compartment (compartment $K$ ) and the compartment with the highest load of added algal biomass (compartment $A$, with $0.3 \mathrm{~g}$ dry weight of algal biomass per $\mathrm{cm}^{2}$ sediment) were selected for the present study. Measurements were made in the recovered sediment after incubation periods of $6 \mathrm{wk}$ at $4^{\circ} \mathrm{C}$ and for an additional $4 \mathrm{wk}$ at $15^{\circ} \mathrm{C}$ and at intermittent light:dark cycles of $8: 16 \mathrm{~h}$.

Gotland Basin: Prolonged stagnation periods with sulfidic conditions are characteristic for the deeper basins of the Baltic Sea. Depending on irregular intrusions of salt water into the Baltic Sea, transient oxic conditions occur in the water column and at the sediment surfaces of the Gotland Deep. Samples were taken at $241 \mathrm{~m}$ depth in the central part of the Basin $\left(57^{\circ} 18.51^{\prime} \mathrm{N}, 20^{\circ} 06.88^{\prime} \mathrm{E}\right)$ in June 1994 , after oxic water had completely replaced the sulfidic deep water, and in October 1995, when sulfide concentrations in the upper sediment layers had increased again and sulfide had already penetrated into the water column (Piker et al. 1998).

In coastal sediments cores were taken with 15 to $30 \mathrm{~cm}$ long cylinders of plexiglas, in the Gotland Basin with a gravity corer (Rumohr-Lot) fitted with $1 \mathrm{~m}$ long liners. Necessary storage was at in situ temperatures (experimental sediment system $15^{\circ} \mathrm{C}$. Hiddensee $10^{\circ} \mathrm{C}$, Gotland Basin $4^{\circ} \mathrm{C}$ ). Cores were cut into 0.1 to $2.0 \mathrm{~cm}$ slices and, depending on the heterogeneity of the habitats, corresponding slices from 3 to 5 cores were mixed under a nitrogen atmosphere and used for further analyses

Bacteria used during this study. As reference strains Paracoccus versutus (formerly Thiobacillus versutus, Katayama et al. 1995) DSM 582 ${ }^{\top}$, Thiobacillus thioparus DSM $505^{\mathrm{T}}$ and Paracoccus denitrificans DSM $65^{\mathrm{T}}$ were obtained from the Deutsche Sammlung von Mikroorganismen und Zellkulturen (DSMZ, Braunschweig, Germany).

Determination of viable cell numbers. Aliquots of the sediment samples were diluted in artificial sea water mineral salts medium (MSM) $(8.2 \mathrm{~g} \mathrm{NaCl}, 0.4 \mathrm{~g}$ $\mathrm{MgCl}_{2} \cdot 6 \mathrm{H}_{2} \mathrm{O}, 0.35 \mathrm{~g} \mathrm{MgSO}_{4} \cdot 7 \mathrm{H}_{2} \mathrm{O}, 0.35 \mathrm{~g} \mathrm{KCl}, 0.2 \mathrm{~g}$ $\mathrm{CaCl}_{2} \cdot 2 \mathrm{H}_{2} \mathrm{O}$, and $0.03 \mathrm{~g} \mathrm{KBr} \mathrm{l}^{-1}$ ), which was adjusted to 15 PSU salinity. From the appropriate dilutions $0.1 \mathrm{ml}$ was streaked onto agar plates with TSB (trypticase soya broth, Becton Dickinson, Cockeysville, MD, USA) and THSTh (synthetic medium for thiobacilli) media and incubated at $15^{\circ} \mathrm{C}$ under aerobic conditions in the dark.

The numbers of bacteria on TSB agar (TSB $10 \mathrm{~g} \mathrm{l}^{-1}$ $\mathrm{NaCl} 4.5 \mathrm{~g} \mathrm{l}^{-1}$, Biomatik 'type BRC AB' agar, $18 \mathrm{~g} \mathrm{l}^{-1}$, $\mathrm{pH} \mathrm{7.2)}$ were determined after 2 wk of incubation. Numbers of sulfur oxidizing bacteria were estimated by using the synthetic THSTh medium that also proved to be suitable for the rultivation of Paracoccus versutus, $P$. denitrificans and Thiobacillus thioparus (in this case without acetate). Colonies on this medium were counted after 3 to $4 \mathrm{wk}$ of incubation. Purification and isolation of sulfur oxidizing bacteria was done by repeated dilution on agar plates with the THSTh medium.

In a final volume of $1 \mathrm{l}$, THSTh medium contained the following components that were sterilized separately and mixed after cooling (the final pH was adjusted to 7.2): Solution A, $250 \mathrm{ml} \mathrm{4-fold} \mathrm{concentrated}$ 
artificial sea water MSM; Solution B, $0.1 \mathrm{~g} \mathrm{NH}_{4} \mathrm{Cl}, 0.7 \mathrm{~g}$ sodium acetate, $0.15 \mathrm{~g} \mathrm{KH}_{2} \mathrm{PO}_{4}, 0.8 \mathrm{~g} \mathrm{~K}_{2} \mathrm{HPO}_{4}$ in $250 \mathrm{ml}$ aqua dest; Solution C, $20 \mathrm{~g}$ Biomatik 'type BRC AB' agar in $400 \mathrm{ml}$ aqua dest.

The following components were prepared separately as stock solutions, sterilized by filtration and added to a final volume of $1 \mathrm{l}$ medium: $5 \mathrm{ml} 0.2 \% \mathrm{FeCl}_{3} \cdot 6 \mathrm{H}_{2} \mathrm{O}$ $5 \mathrm{ml} 0.35 \% \mathrm{MnCl}_{2}-4 \mathrm{H}_{2} \mathrm{O}, 50 \mathrm{ml} 10 \% \mathrm{Na}_{2} \mathrm{~S}_{2} \mathrm{O}_{3} \cdot 5 \mathrm{H}_{2} \mathrm{O}$ $10 \mathrm{ml} 0.12 \% \quad \mathrm{Na}_{2} \mathrm{~S} \cdot 9 \mathrm{H}_{2} \mathrm{O}, 1 \mathrm{ml} \quad 0.15 \%$ yeast extract (Merck), $1 \mathrm{ml}$ trace element solution TET2, $1 \mathrm{ml}$ vitamin solution VA (Imhoff 1988), and $1 \mathrm{ml}$ stock solution of vitamin $\mathrm{B}_{12}$ (containing $15 \mu \mathrm{g} \mathrm{l}^{-1}$ ).

TET2 contained the following components: $50.0 \mathrm{~g}$ EDTA, $0.4 \mathrm{~g} \mathrm{ZnCl}_{2}, 3.0 \mathrm{~g} \mathrm{MnCl}_{2} \cdot 4 \mathrm{H}_{2} \mathrm{O}, 4.0 \mathrm{~g} \mathrm{FeCl}_{2}$ $4 \mathrm{H}_{2} \mathrm{O}, 10.0 \mathrm{~g} \mathrm{FeCl} \cdot 6 \mathrm{H}_{2} \mathrm{O}, 0.4 \mathrm{~g} \mathrm{Na} \mathrm{NaO}_{4} \cdot 2 \mathrm{M}_{2} \mathrm{O}$, $0.04 \mathrm{~g} \mathrm{CuCl}_{2} \cdot 2 \mathrm{H}_{2} \mathrm{O}, 0.24 \mathrm{~g} \mathrm{CoCl}_{2} \cdot 6 \mathrm{H}_{2} \mathrm{O}, 0.4 \mathrm{~g} \mathrm{H}_{3} \mathrm{BO}_{3}$, $0.01 \mathrm{~g} \mathrm{NiCl}_{2} \cdot 6 \mathrm{H}_{2} \mathrm{O}, 0.001 \mathrm{~g} \mathrm{Na}_{2} \mathrm{SeO}_{3} \cdot 5 \mathrm{H}_{2} \mathrm{O}$ per liter aqua dest.

Chemical analyses. The content of organic material was determined as percentage of the dry weight of the sediment by heating at $550^{\circ} \mathrm{C}$ for $5 \mathrm{~h}$.

Chemical parameters were determined in sediment pore water, which was recovered after centrifugation at $4000 \mathrm{U} \mathrm{min}^{-1}$ (approx. $1700 \times g$ ) in a Sigma $3 \mathrm{~K} 30$ centrifuge under an atmosphere of argon or dinitrogen. For the determination of sulfide, samples were taken immediately after centrifugation and fixed in gas-tight tubes containing $5 \mathrm{ml} 2 \% \mathrm{Zn}$ acetate.

Sulfide was determined photometrically as methylene blue (absorbance at $668 \mathrm{~nm}$ ) according to Pachmayr (1960). For the determination of sulfate, sulfite, thiosulfate and tetrathionate, pore water and culture fluids were filtered through a $0.2 \mu \mathrm{m}$ pore size cellulose acetate filter (Sartorius, Göttingen, Germany). Sulfate, sulfite and thiosulfate were separated on an anion exchange column (Ionpack-AS4A, Dionex, Idstein, Germany) and eluted with $1.7 \mathrm{mM} \mathrm{NaHCO}_{3}+$ $1.8 \mathrm{mM} \mathrm{Na}_{2} \mathrm{CO}_{3}$ (flow rate was $2 \mathrm{ml} \mathrm{min}^{-1}$ ). Thiosulfate and tetrathionate were separated by ion-pair chromatography (Dionex ionpack-NS1 column) and eluted with $2 \mathrm{mM}$ tetrabutylammonium hydroxide, $0.88 \mathrm{mM}$ $\mathrm{Na}_{2} \mathrm{CO}_{3}, 30 \%$ acetonitrile. Quantitative analyses were made using suppressed conductivity and UVabsorbance at 215 and $254 \mathrm{~nm}$, respectively, for detection. Tetrathionate standards were stable during the analytical procedure and did not give indication of degradation during storage at $-20^{\circ} \mathrm{C}$ for up to a week. Elemental sulfur was determined according to Chan \& Suzuki (1993). Samples of $1 \mathrm{~cm}^{3}$ sediment were mixed with $1 \mathrm{ml}$ artificial seawater (MSM) and extracted with $2 \mathrm{ml}$ petrol ether. An aliquot of the petrol ether phase $(0.5 \mathrm{ml})$ was mixed with $1 \mathrm{ml} \mathrm{NaCN}$ solution $(0.075 \%$ in $95 \%$ acetone) and $1 \mathrm{ml} 95 \%$ acetone. After $2 \mathrm{~min}$, $1 \mathrm{ml} \mathrm{FeCl}_{3}$ solution ( $2 \%$ in $95 \%$ acetone) was added and the extinction measured at $464 \mathrm{~nm}$ within $10 \mathrm{~min}$.
Measurements of thiosulfate oxidation. The potential of thiosulfate transformations within the sediments was measured under standard conditions. An aliquot of $1 \mathrm{~cm}^{3}$ sediment was suspended in $50 \mathrm{ml}$ THSTh medium (containing $\mathrm{MSM}$ with $\mathrm{MgSO}_{4} \cdot 7 \mathrm{H}_{2} \mathrm{O}$ replaced by equimolar amounts of $\mathrm{MgCl}_{2} \cdot 6 \mathrm{H}_{2} \mathrm{O}$ ) and preincubated for $12 \mathrm{~h}$ under aerobic conditions on a rotary shaker $(100 \mathrm{rpm})$ prior to the addition of acetate $(0.25 \mathrm{mM})$ and thiosulfate $(1 \mathrm{mM})$. Thereafter the mixtures were incubated for another $24 \mathrm{~h}$ (samples from Hiddensee at $20^{\circ} \mathrm{C}$ and samples from the experimental sediment at $15^{\circ} \mathrm{C}$ ), then filtered through $0.2 \mu \mathrm{m}$ pore size cellulose acetate filters and frozen at $-20^{\circ} \mathrm{C}$ until use for chemical analysis. The turnover rates were expressed as $\mu$ mol thiosulfate transformed per hour and $\mathrm{cm}^{3}$ of sediment.

Oxidation rates of thiosulfate by pure cultures were determined in THSTh medium containing $1 \mathrm{mM}$ thiosulfate and $0.25 \mathrm{mM}$ acetate. After $24 \mathrm{~h}$ incubation at $20^{\circ} \mathrm{C}$ aliquots were taken for analyses of elemental sulfur and ion chromatographic analysis of sulfur compounds. The latter were frozen at $-20^{\circ} \mathrm{C}$ after sterile filtration.

Fatty acid analysis. Fatty acid analysis was made essentially as outlined in the standardized procedures of the Microbial Identification System (MIS, MIDI Incorp., Newark, Delaware, USA). The growth conditions were changed slightly. Agar plates contained $0.3 \% \mathrm{TSB}, 5 \mathrm{~g} \mathrm{Na}_{2} \mathrm{~S}_{2} \mathrm{O}_{3} \cdot 5 \mathrm{H}_{2} \mathrm{O}, 1 \mathrm{ml}$ VA (Imhoff 1988), $1 \mathrm{ml}$ TET2 and $15 \mathrm{~g}$ agar in artificial sea water of $5 \mathrm{PSU}$ salinity. Final pH was 7.2. Plates were incubated at $28^{\circ} \mathrm{C}$ for $7 \mathrm{~d}$. Harvesting of cells, extraction procedures and gas chromatographic analysis were made as described by Thiemann \& Imhoff (1996).

\section{RESULTS}

\section{Sites of investigations}

Sediments of the Baltic Sea investigated during this study were rich in organic matter. They were known to frequently develop massive blooms of phototrophic and/nr chemotrophic sulfur bacteria. Oxygen pene trated only into the uppermost few millimeters of these sediments and sulfidic conditions regularly were found close to the sediment surface. Often sulfide penetrated into the water above the sediment. Two of the sites (Hiddensee and Bottsand) were coastal habitats, one was a deep basin sediment (Gotland Deep).

The sediment of Hiddensee consisted of a fine silty material mixed with large amounts of decaying seaweed in the top $10 \mathrm{~cm}$ overlying a coarse sandy sediment. The content of organic matter was 2 to $10 \%$ of the sediment dry weight. During the investigations in 


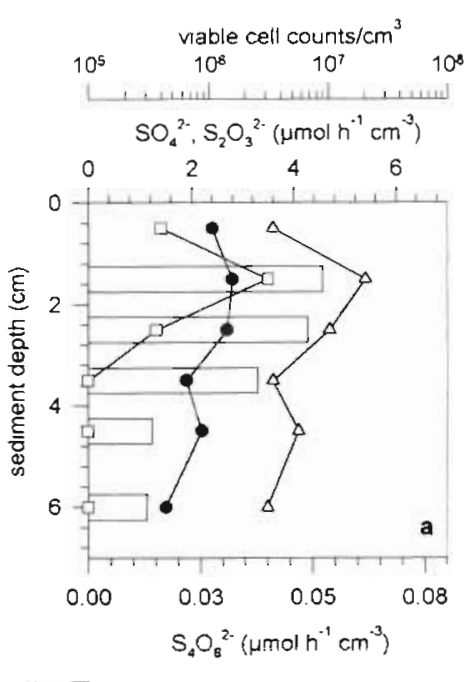

sulfur-oxidizing bacteria

- thiosulfate $\triangle$ sulfate $\square$ tetrathionate

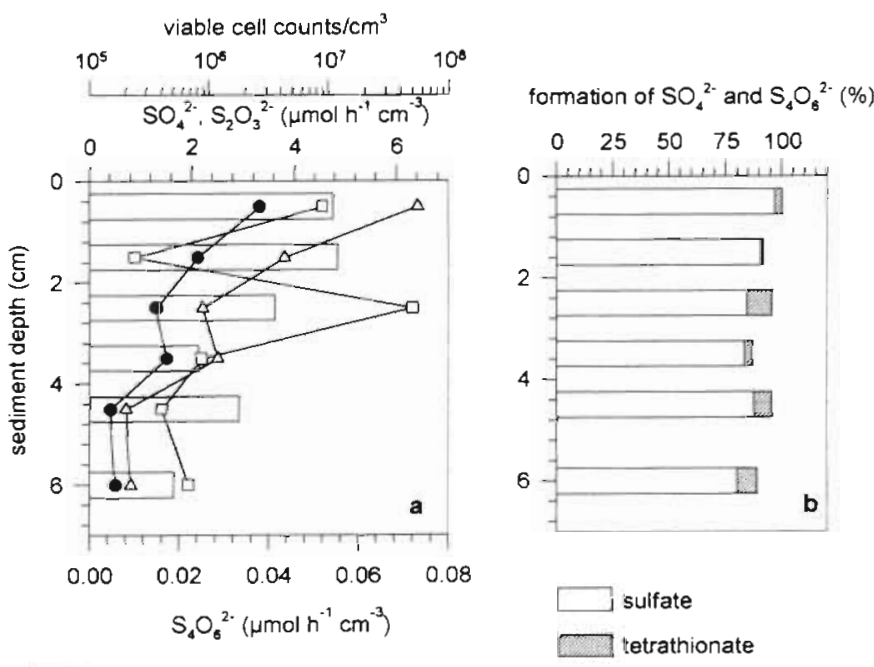

sulfur-oxidizing bacteria

- thiosulfate $\triangle$ sulfate $\square$ tetrathionate

November 1993 the redox potential was $+210 \mathrm{mV}$ at the sediment surface of the uncovered area compared to $-200 \mathrm{mV}$ at the covered area. The sediment of the Bottsand had a high content of fine and coarse sandy material and contained up to $4 \%(0.1$ to $4.0 \%)$ of organic matter by sediment dry weight. The silty sediment of the Gotland Deen was characterized hy very high contents of water $(95 \%$ at $10 \mathrm{~cm}$ depth) and organic matter ( 15 to $30 \%$ of the sediment dry weight) within the top $20 \mathrm{~cm}$.

\section{Bacterial cell counts within the sediments}

The numbers of sulfur oxidizing bacteria were determined by using a mineral salts medium with additions of thiosulfate and acetate as energy and carbon sources

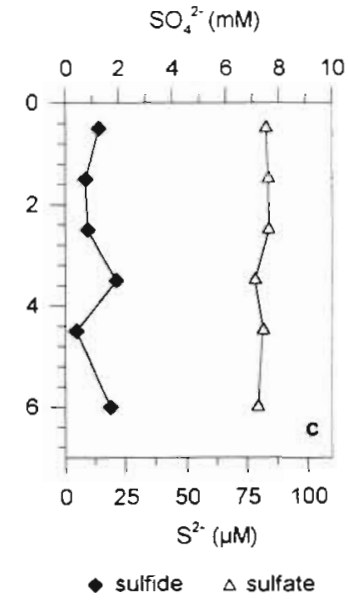

Fig. 1. Untreated natural sediment at Hiddensee $\mathrm{K}$ (control). (a) Viable cell counts of sulfur oxidizing bacteria, transformation rates of thiosulfate $\left(\mathrm{S}_{2} \mathrm{O}_{3}{ }^{2-}\right)$ and formation rates of sulfate $\left(\mathrm{SO}_{4}{ }^{2-}\right)$ and tetrathionate $\left(\mathrm{S}_{4} \mathrm{O}_{6}{ }^{2-}\right)$ (b) Oxidation of thiosulfate to sulfate and tetrathionate in percent transformed thiosulfate sulfur. (c) Depth profiles of sulfide $\left(\mathrm{S}^{2-}\right)$ and sulfate $\left(\mathrm{SO}_{4}{ }^{2-}\right)$ in the pore water thiosulfate and tetrathionate were not detected

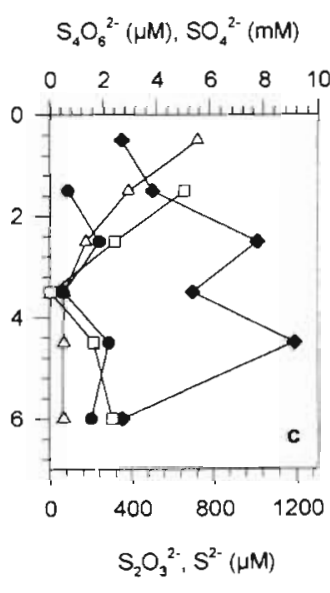

- sulfide $\Delta$ sulfate

- thiosulfate $\square$ tetrathionate
Fig. 2. Sediment at Hiddensee $K$ after 5 mo of artificial anoxic conditions. (a) Viable cell counts of sulfur oxidizing bacteria, transformation rates of thiosulfate $\left(\mathrm{S}_{2} \mathrm{O}_{3}{ }^{2-}\right)$ and formation rates of sulfate $\left(\mathrm{SO}_{4}{ }^{2-}\right)$ and tetrathionate $\left(\mathrm{S}_{4} \mathrm{O}_{6}{ }^{2-}\right)$. (b) Oxidation of thiosulfate to sulfate and tetrathionate in percent transformed thiosulfate sulfur. (c) Depth profiles of sulfide $\left(\mathrm{S}^{2-}\right)$, sulfate $\left(\mathrm{SO}_{4}{ }^{2-}\right)$, thiosulfate $\left(\mathrm{S}_{2} \mathrm{O}_{3}{ }^{2-}\right)$ and tetrathionate $\left(\mathrm{S}_{4} \mathrm{O}_{6}{ }^{2-}\right)$ in the pore water

(THSTh). This medium was suitable to cultivate representative chemotrophic sulfur bacteria such as Thiobacillus thioparus and Paracoccus versutus, which were used as reference organisms during this study. All of the investigated isolates, which represented the most numerous bacteria growing under these conditions, were able to oxidize thiosulfate. For simplicity, viable numbers obtained on THSTh medium will be called sulfur oxidizing bacteria in the following. Primarily chemoheterotrophic (and possibly facultative chemoautotrophic), but not obligately chemolithoautotrophic sulfur oxidizing bacteria were ob- tained with this medium, as was concluded from the properties of the isolated bacteria (see below). Numbers of these bacteria were compared to those of bacteria growing on a complex standard medium (TSB), in the following called chemoorganotrophic bacteria for simplicity. 
Fig. 3. Transformation of thiosulfate in the untreated experimental sediment system (compartment K). (a) Viable cell counts of sulfur oxidizing bacteria, ratio of sulfur oxidizing bacteria and chemoorganotrophic bacteria and the content of organic matter tion $\left(\mathrm{S}_{2} \mathrm{O}_{3}{ }^{2-}\right)$ and formation of sulfate $\left(\mathrm{SO}_{4}{ }^{2-}\right)$ and tetrathionate $\left(\mathrm{S}_{4} \mathrm{O}_{6}{ }^{2-}\right)$. (c) Oxidation of thiosulfate to sulfate of transformed thiosulfate sulfur (b) Rates of thiosulfate oxidaand tetrathionate in percent
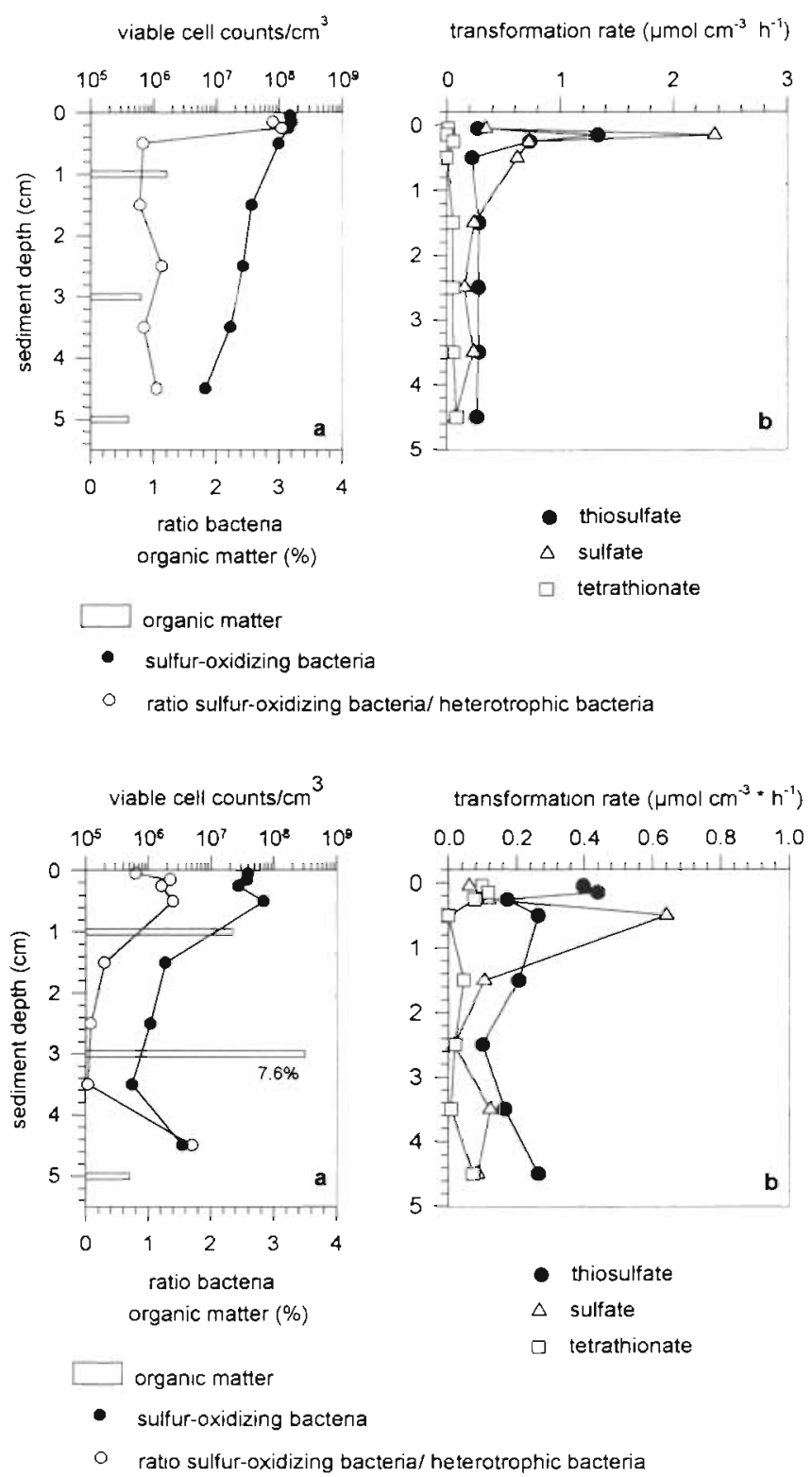

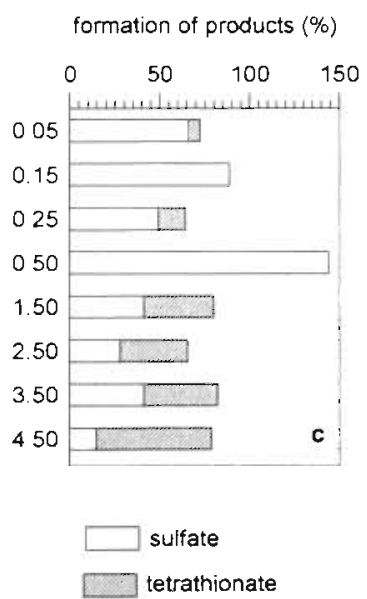

formation of products (\%)

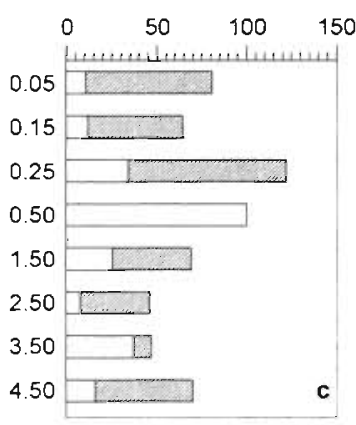

trophic bacteria and the content of organic matter (b) Rates of thiosulfate oxidation $\left(\mathrm{S}_{2} \mathrm{O}_{3}{ }^{2-}\right)$ and formation of sulfate $\left(\mathrm{SO}_{4}{ }^{2}\right)$ and tetrathionate $\left(\mathrm{S}_{4} \mathrm{O}_{6}{ }^{2}\right)$. (c) Oxidation of thiosulfate to sulfate and tetrathionate in percent of transformed thiosulfate sulfur thiosulfate in the experimenpartment A). (a) Viable cel counts of sulfur oxidizing bacteria, ratio of sulfur oxidizing bacteria and chemo-
Fig. 4. Transformation of high organic content (cor
Numbers of sulfur oxidizing bacteria growing on THSTh medium varied from $10^{5}$ to $10^{8}$ cells $\mathrm{cm}^{-3}$ in the investigated sediments. In correlation with the potential oxidation rates of thiosulfate, maxima of sulfur oxidizing bacteria were always found at or close to the sediment surface (see also Imhoff et al. 1995). Numbers of sulfur oxidizing bacteria at Hiddensee decreased from approx. $10^{7} \mathrm{~cm}^{-3}$ close to the sediment surface to approx. $5 \times 10^{5} \mathrm{~cm}^{-3}$ at $6 \mathrm{~cm}$ depth (Figs. $1 \mathrm{a} \& 2 \mathrm{a}$ ). The protection of the sediment by a plastic cover sheet had no significant influence on these numbers. In the experimental sediment system numbers of sulfur oxidizing bacteria were similar in both areas, with $10^{8}$ cells $\mathrm{cm}^{-3}$ at the sediment surface (Figs. 3a \& 4a) and approx. $10^{7}$ cells $\mathrm{cm}^{-3}$ at $5 \mathrm{~cm}$ depth, with a minimum at the depth where the organic matter had been added in compartment $\mathrm{A}$ (Fig. $4 \mathrm{a}$ ). In the most active top layers of the sediments their numbers exceeded those of the bacteria growing on TSB medium (see Figs. $3 a \& 4$ a).

\section{Concentration profiles of sulfur compounds}

Concentration profiles of sulfur compounds were highly variable and dependent on the environmental conditions. Limitation of oxygen penetration into the sediment and increased supply of degradable organic matter favored active sulfate reduction. Zones of increased sulfide concentrations indicated short-term activation of sulfate reduction, while zones of sulfate depletion were due to highly active sulfate reduction for prolonged time periods. 
The most obvious difference between the 2 sediment compartments of Hiddensee was the rather stable concentration of sulfate $(8 \mathrm{mM})$ throughout the sediment depth in the control area and its strong depletion to approx. $6 \mathrm{mM}$ at the surface and to concentrations of less than $1 \mathrm{mM}$ below $3 \mathrm{~cm}$ sediment depth in the covered sediment (Fig. 2c). This depletion was correlated with strongly increased concentrations of sulfide (up to $1.25 \mathrm{mM}$ ) and thiosulfate (up to $250 \mu \mathrm{M}$ ) and the accumulation of significant amounts of tetrathionate (up to $6 \mu \mathrm{M}$ ) (Fig. 2c). In the uncovered area sulfide was present at low concentrations throughout the sediment profile (10 to $25 \mu \mathrm{M}$, Fig. 1c) and concentrations of both thiosulfate and tetrathionate were below the detection limit of 0.5 and $1.0 \mu \mathrm{M}$, respectively.

The massive inflow of oxic bottom water into the Gotland Basin and the following depletion of oxygen at the sediment surface and in the water caused dynamic changes in the chemistry and the profiles of sulfur compounds within the upper sediment layers (Piker et al. 1998). Compared to June 1994, concentrations of sulfide and elemental sulfur had increased dramatically in October 1995, and at that time elemental sulfur represented a major fraction of the total sulfur of these sediments. In addition, significant concentrations of thiosulfate and tetrathionate were present (Fig. 5).

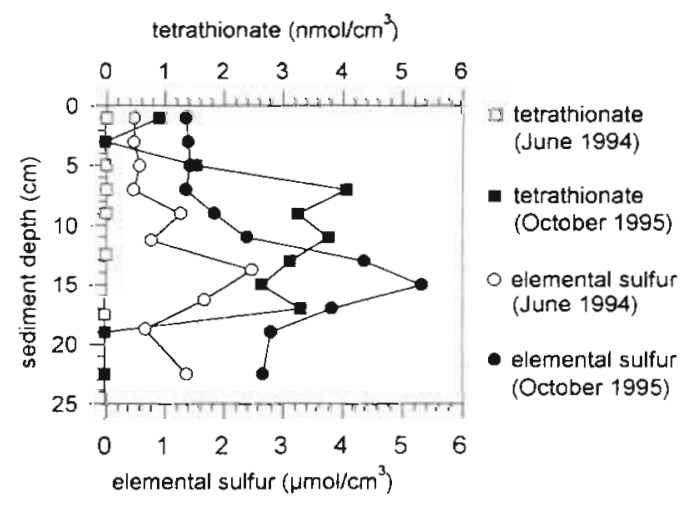

Fig. 5. Depth profiles of the concentrations of tetrathionate and elemental sulfur in June 1994 during oxic conditions and in October 1995 during anoxic conditions in the Gotland Basin

\section{Thiosulfate oxidation within the sediments}

In all investigated sediments significant rates of thiosulfate transformation were found.

\section{Sediment at Hiddensee}

The profiles of potential thiosulfate oxidation correlated well with those of cell numbers of sulfur oxidizing bacteria. In the uncovered sediment the highest rates of thiosulfate oxidation $\left(2.8 \mu \mathrm{mol} \mathrm{h} \mathrm{h}^{-1} \mathrm{~cm}^{-3}\right)$, together with those of sulfate and tetrathionate formation, were found at 1 to $2 \mathrm{~cm}$ depth (Fig. 1a). In the covered sediment area, maximum values of these activities moved to the sediment surface and a second strong maximum of tetrathionate formation was found at approx. $3 \mathrm{~cm}$ depth (Fig. 2a). Sulfate was the major oxidation product of thiosulfate in all sediment layers of both areas. However, the proportion of tetrathionate formed was higher in the covered sediment than in the uncovered control sediment. It reached up to $4.1 \%$ of the total transformed thiosulfate sulfur in the former compared to $1.2 \%$ in the latter (Table 1 , Figs. $1 \mathrm{~b} \& 2 \mathrm{~b}$ ).

\section{Experimental sediment system}

Rates of potential thiosulfate oxidation were highest at or close to the sediment surface in both compartments of this sediment system. In the control compartment a sharp peak of potential thiosulfate oxidation close to the sediment surface correlated strongly with a maximum of sulfate formation. Sulfate was the predominant or sole oxidation product in the top part of this sediment, while below $1 \mathrm{~cm}$ depth considerable proportions of tetrathionate were formed (Fig. 3c). In sediments of the treated compartment, tetrathionate was the major product of thiosulfate oxidation in the surface layers as well as in deeper parts (Fig. 4c, Table 1). However, the overall potential of thiosulfate oxidation was significantly lower in this compartment (Figs. $3 b \& 4 b$ ).

Table 1 Oxidation rates of thiosulfate $\left(\mathrm{TS}_{i} \mu \mathrm{mol} \mathrm{h} \mathrm{h}^{-1} \mathrm{~cm}^{-3}\right.$ ) and formation of the products suifate (SA) and terrathiondie (TIj) in percent of transformed thiosulfate sulfur in the experimental sediment system (control compartment $\mathrm{K}$ with $0.9 \%$ organic matter of the dry weight and compartment A with organic matter enriched to $2.2 \%$ ) and in coastal sediments of Hiddensee (untreated area in comparison to an artificial anoxic area). Rates were integrated over 2 depths of the sediments

\begin{tabular}{|c|c|c|c|c|c|c|c|c|c|c|c|c|}
\hline & \multicolumn{6}{|c|}{ Experimental sediment } & \multicolumn{6}{|c|}{ Sediment at Hiddensee } \\
\hline & \multicolumn{3}{|c|}{ Compartment $\mathrm{K}$} & \multicolumn{3}{|c|}{ Compartment $\mathrm{A}$} & \multicolumn{3}{|c|}{ Untreated } & \multicolumn{3}{|c|}{ Anoxic } \\
\hline & TS & SA & $\mathrm{TT}$ & TS & $\mathrm{SA}$ & TT & TS & SA & TT & TS & $\mathrm{SA}$ & TT \\
\hline $0-3 \mathrm{~mm}$ & 2.3 & 73.6 & 5.5 & 1 & 24.8 & 57.4 & - & - & - & - & - & - \\
\hline $0-5 \mathrm{~cm}$ & 1.5 & 53.6 & 32.8 & 1.1 & 45 & 31.4 & 12 & 89.2 & 1.2 & 8.6 & 90.7 & 4.1 \\
\hline
\end{tabular}




\section{Aerobic sulfur oxidizing bacteria isolated from the investigated sediments}

Sulfur oxidizing bacteria were isolated from sediments of different locations at the shoreline and in central parts of the Baltic Sea. It became quite obvious during isolation and cultivation experiments that some of these bacteria occurred frequently and were present in different sediments.

Using the database of the MIDI system, including reference strains of Paracoccus denitrificans, P. versutus and Shewanella putrefaciens, representative isolates of thiosulfate oxidizing bacteria were characterized by their fatty acid composition. Accordingly, strains B3, B17 and B11 formed a cluster similar to $P$. denitrificans and $P$. versutus (data not shown). Total viable numbers of bacteria represented by strains such as B3 were approx. $2 \times 10^{7} \mathrm{ml}^{-1}$ in the Bottsand sediment ( 0 to $1 \mathrm{~cm}$ depth), correlating to $18 \%$ of total sulfur oxidizing bacteria at this particular place. Another group of bacteria with transparent beige-colored colonies containing small rod-shaped cells (strains BS1, BS8 and BS9) always represented a major fraction of viable cell counts of sulfur oxidizing bacteria and was common to different sediments. According to their fatty acid composition, these bacteria were most similar to Pseudomonas stutzeri. The identification of strain BS8 was substantiated by 16 S rDNA analyses. Although the fatty acid composition of some additional strains was moderately similar to that of $S$. putrefaciens, the composition of a larger number of other isolates was not particularly similar to any other bacteria of the database. According to the analyses, these strains belonged to the gamma-Proteobacteria and to the Gram-positive bacteria, respectively (data not shown).

\section{Thiosulfate oxidation by isolated sulfur oxidizing bacteria}

Thiosulfate oxidation was exhibited by all bacteria selected from dilution plates of THSTh medium. However, in contrast to the oxidation reactions of Paracoccus versutus and Thiobacillus thioparus, which form sulfate as the major and final oxidation product, isolates selected during this study oxidized thiosulfate to varying amounts of tetrathionate, elemental sulfur and sulfate (Fig. 6). The products and their proportions varied greatly between the different isolates. Strain B17, which was similar to $P$. versutus and $P$. denitrificans according to the fatty acid composition, only formed tetrathionate, while the unidentified strain $\mathrm{HK} 9 \mathrm{~b}$ nearly exclusively produced sulfate. In the mass balances of the sulfur compounds of both strains, consid-

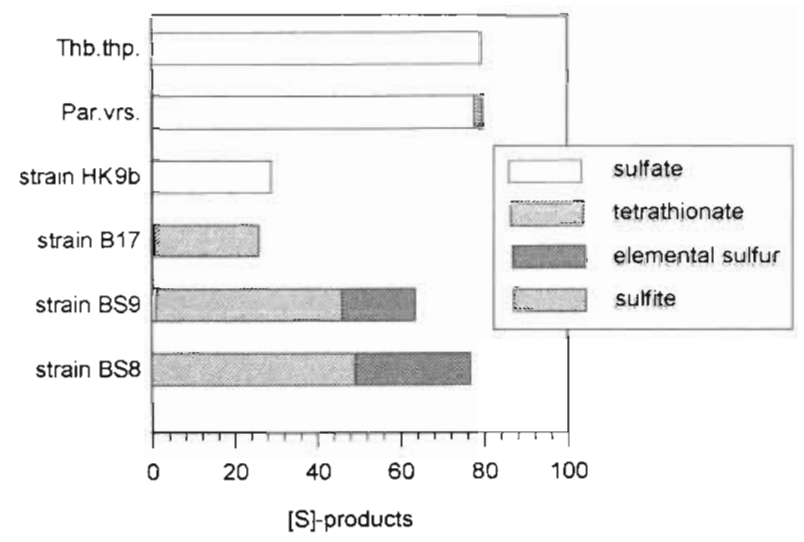

Fig. 6. Product formation during the oxidation of thiosulfate by Thiobacillus thioparus (Thb. thp.), Paracoccus versutus (Par. vrs.) and a few selected sulfur-oxidizing bacteria isolated

from Baltic Sea sediments; sulfite was not detected

erable amounts of unidentified oxidation products were missing; from observations with cultures and microscopic examinations elemental sulfur can be excluded as one of the major missing products of these 2 strains. Although an appropriate standard of trithionate was not available, significant amounts of this component would have been detected in the elution profile of the used chromatographic column. Therefore trithionate quite unlikely is contributing to the missing balance of oxidation products. Similarly sulfite would have been detected, if present. Two isolates of Pseudomonas stutzeri (strains BS8 and BS9) did not form sulfate but instead tetrathionate $(40$ to $50 \%$ of the thiosulfate sulfur) as the major product, together with appreciable amounts of elemental sulfur (15 to $30 \%$ ).

\section{DISCUSSION}

\section{General aspects of the sulfur cycle}

Discussions on the biogeochemistry of sulfur are governed by the role and interactions of sulfide, sulfate and elemental sulfur (Jørgensen 1988, Kelly 1988 , Ehrlich 1990). This is reflected in our knowledge of transformations of sulfur compounds by various bacteria. We understand very well the processes of sulfate reduction to sulfide by eubacterial but also archaebacterial sulfate reducers (Widdel 1988) and the oxidation reactions by phototrophic bacteria and chemolithotrophic sulfur oxidizing bacteria (e.g. Trüper 1975 , Kuenen et al. 1992). In many cases elemental sulfur is an intermediate in the oxidation of sulfide to sulfate either inside the cells (e.g. Chromatiaceae, Beggiatoa spp.) or outside (Chlorobium spp., Thiobacillus spp.). These are the most impressive examples of sulfur bacteria and therefore have been most intensively studied. 
In other bacteria, the intermediate formation of elemental sulfur was not detected and sulfide is oxidized to sulfate without stable intermediates, as in Rhodovulum sulfidophilum (Neutzling et al. 1985) or in many thiobacilli, which form various mixtures of polythionates as intermediates in the oxidation of reduced sulfur compounds (Kuenen et al. 1992).

Many of the more recent findings on sulfur transformations by pure cultures and in the natural environment have extended this view. Most important was the recognition of the central role of thiosulfate in the sediment biogeochemistry by extended studies of Jørgensen and coworkers (e.g. Jørgensen 1990, Jørgensen \& Bak 1991) that shed light on the role of thiosulfate in oxidative, reductive and disproportionation processes. The ability of bacteria to gain energy out of the disproportionation not only of thiosulfate but also of other sulfur compounds of intermediate redox state, such as sulfite and elemental sulfur, enlarges the possibilities of transformations in the natural environment and of possible interactions between 'sulfur bacteria' (Bak \& Pfennig 1987, Canfield \& Thamdrup 1996). More than any other findings, these results have demonstrated the participation of sulfur compounds of intermediate redox state in oxidative as well as in reductive processes. Not only can these compounds undergo oxidative as well as reductive reaction sequences, but they also may be produced during dissimilatory processes as oxidation products or as reduction products. In fact, thiosulfate and trithionate, and to a lesser extent also tetrathionate, have been found as intermediates during sulfate and sulfite reduction by cultures of sulfate reducing bacteria from freshwater and marine sources (Fitz \& Cypionka 1990, Sass et al. 1992). Tetrathionate also can be reduced by a number of bacteria that are not sulfate reducers (Barrett \& Clark 1987). On the other hand, tetrathionate (and other thionates) is also well known as an intermediate in the oxidation of reduced sulfur compounds to sulfate by Thiobacillus tepidarius, $T$. intermedius and other thiobacilli (Wood \& Kelly 1986, Lu \& Kelly 1988, Kuenen et al. 1992, Wentzien et al. 1994).

\section{Bacterial and chemical formation and reartions of tetrathionate}

With the recognition of the central role of thiosulfate in the sulfur cycle of marine sediments (Jørgensen 1990), tetrathionate should also receive more attention, because both compounds are readily transformed into each other by a number of chemical and biological reactions.

Textbooks of inorganic chemistry characterize polythionates like tetrathionate as rather instable com- pounds that undergo gradual degradation to elemental sulfur, sulfurous acid and sulfuric acid under acidic conditions and to thiosulfate and sulfite under alkaline conditions (Hollemann \& Wiberg 1971). Tetrathionate reacts with sulfite readily to produce thiosulfate and trithionate (Hollemann \& Wiberg 1971). Under alkaline conditions tetrathionate may also undergo asymmetrical hydrolysis to thiosulfate, elemental sulfur and sulfate according to $\mathrm{S}_{4} \mathrm{O}_{6}{ }^{2-}+\mathrm{OH}^{-} \rightarrow \mathrm{S}_{2} \mathrm{O}_{3}{ }^{2-}+\mathrm{S}^{\circ}+\mathrm{HSO}_{4}^{-}$ (Roy \& Trudinger 1970). Also the enzymatically catalyzed reaction $\mathrm{S}_{4} \mathrm{O}_{6}{ }^{2-}+\mathrm{H}_{2} \mathrm{O} \rightarrow 2 \mathrm{HS}_{3} \mathrm{O}_{3}{ }^{-}+\mathrm{SO}_{4}{ }^{2-}+\mathrm{H}^{+}$is favored under alkaline conditions (Steudel et al. 1987). This reaction may explain the formation of tetrathionate and elemental sulfur from thiosulfate by the strains of Pseudomonas stutzeri in this study, because the intermediate disulfane-monosulfonate is highly unstable and readily forms elemental sulfur (Wentzien et al. 1994). The presence of this reaction sequence and the participating enzymes in P. stutzeri still have to be proven.

Also, the chemical reaction of tetrathionate with sulfide to form elemental sulfur and thiosulfate has been known for a long time (Roy \& Trudinger 1970). The impact of this reaction on product formation by bacterial cultures oxidizing sulfide to tetrathionate was first recognized by Hansen (1974), working with the phototrophic purple nonsulfur bacterium Rhodomicrobium vannielii. This bacterium oxidizes sulfide to tetrathionate as final product (Hansen 1974). However, the stoichiometric transformation was observed only in chemostat cultures with limiting sulfide concentrations. When grown in batch cultures with higher concentrations of sulfide, elemental sulfur and thiosulfate were formed as products of the reaction of sulfide with the tetrathionate formed by $R$. vannielii according to $\mathrm{S}_{4} \mathrm{O}_{6}{ }^{2-}+\mathrm{S}^{2-} \rightarrow 2 \mathrm{~S}_{2} \mathrm{O}_{3}{ }^{2-}+\mathrm{S}^{\circ}$ (Hansen 1974)

Reports in the literature indicate the exclusive formation of tetrathionate from thiosulfate by a number of chemoheterotrophic bacteria (Mason \& Kelly 1988), but also for the production of tetrathionate and sulfate by others (Durand et al. 1994). The simple oxidation of thiosulfate to tetrathionate appears to be widespread among bacteria and has been found in Klebsiella aerogenes, Bacillus globigii, B. megaterium, Pseudomonas nutida: $P$. fluorescens and $P$. aeruginosa (Mason \& Kelly 1988), but also several marine bacteria (Tuttle \& Jannasch 1973, Sorokin 1992, 1993, 1996, Sorokin et al. 1996). Catenococcus thiocyclus is able to oxidize sulfide and thiosulfate to tetrathionate, but not to sulfate (Sorokin 1992, Sorokin et al. 1996). When cultures of this bacterium were grown with thiosulfate and sulfide was added in addition, growth stimulation occurred and was considered to be due to the sulfide mediated reduction of tetrathionate, which regenerates the electron donor thiosulfate (Sorokin et al. 1996). These 
authors proposed that the chemical reaction of sulfide with tetrathionate led to the accumulation of elemental sulfur and formation of thiosulfate, similar to the situation described for Rhodomicrobium vannielii (Hansen 1974)

\section{Role of tetrathionate in the sediment}

Up to now all discussion on ecological aspects of the role of tetrathionate in the sulfur cycle of the sediments is based either on the analytical detection of tetrathionate in the environment or on transformations with pure cultures like Catenococcus thiocyclus (e.g. Sorokin et al. 1996). The presence of tetrathionate in the natural environment has been reported in a few cases only (Luther et al. 1986, Henneke et al. 1997). With seasonal dependence, extraordinarily high concentrations of up to $300 \mu \mathrm{M}$ tetrathionate were detected in pore waters of the Great Marsh, Delaware (Luther et al. 1986). In the Tyro and Bennock Basins of the Mediterranean Sea concentrations of 11.1 and $20.9 \mu \mathrm{M}$, respectively, were measured (Henneke et al. 1997).

Our results demonstrate that depending on the environmental conditions tetrathionate and sulfate are produced as oxidation products of thiosulfate in different proportions in brackish water sediments. Concentrations of tetrathionate of up to $21.6 \mu \mathrm{M}$ in the pore waters of sediments at Hiddensee and up to $7.5 \mu \mathrm{M}$ in sediments of the Gotland Basin were found. Depth profiles of the distribution of sulfur oxidizing bacteria revealed a strong correlation between viable cell counts of these bacteria and potential rates of thiosulfate oxidation to tetrathionate and sulfate within the Baltic Sea sediments. In addition, pure culture studies with representative isolates proved the ability of the bacteria to oxidize thiosulfate and to form tetrathionate and also sulfate as oxidation products. A preliminary report of this work including a discussion of the cycling

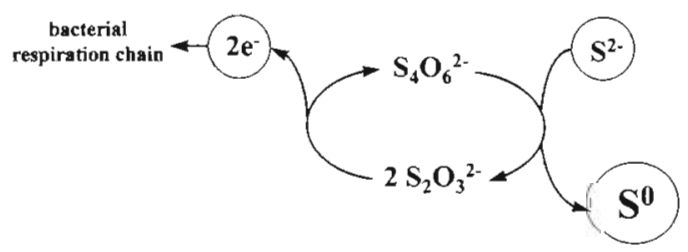

Fig. 7. The tetrathionate cycle. The combined action of bacterial thiosulfate oxidation to tetrathionate and the chemical reactions between sulfide and tetrathionate lead to a cyclic reaction sequence with a net formation of elemental sulfur (Roy \& Trudinger 1970, Hansen 1974). On the basis of these reactions elemental sulfur may accumulate in marine sediments. Such a cycle has been previously proposed on the basis of pure culture studies with Catenococcus thiocyclus by Sorokin et al. (1996) of thiosulfate and tetrathionate and the elemental sulfur accumulation within Baltic Sea sediments has been given before (Imhoff 1996).

Due to the high rates of tetrathionate formation from thiosulfate in sediments (max. $0.1 \mu \mathrm{mol} \mathrm{h} \mathrm{h}^{-1} \mathrm{~cm}^{-3}$ ) as well as by isolated sulfur oxidizing bacteria (e.g. $0.8 \mu \mathrm{mol}$ $\mathrm{h}^{-1} \mathrm{mg}^{-1}$ protein by Pseudomonas stutzeri strain BS8), one could easily be misled into expecting much higher concentrations of tetrathionate in the pore water of these sediments than were actually measured. However, accumulation of tetrathionate to high concentrations is naturally excluded because of its high reactivity not only by biological but also in particular by chemical reactions, as outlined above. Most significantly, in the presence of sulfide it readily reacts to elemental sulfur and thiosulfate as products (Roy \& Trudinger 1970).

Thus, in sulfidic marine environments tetrathionate is an unstable component that does not easily accumulate to detectable quantities unless continued new formation is fast enough to overcome depositional processes. In no way is the size of the tetrathionate pool an indicator of the turnover through the pool. In fact, low concentrations of thiosulfate and tetrathionate are sufficient to promote the large-scale oxidation of sulfide to elemental sulfur by coupled bacterial and chemical reactions. Thereby, bacteria that are unable to utilize sulfide by themselves may be able to gain energy out of the net oxidation of sulfide to elemental sulfur. The chemical reaction of tetrathionate with sulfide (Roy \& Trudinger 1970, Hansen 1974) to produce elemental sulfur and 2 molecules of thiosulfate forms the oxidation product of the overall reaction (elemental sulfur) and reconstitutes the substrate for the bacteria on a stoichiometric basis. Thus, the combined action of bacterial tetrathionate formation from thiosulfate and the chemical reaction with sulfide results in a cyclic turnover of thiosulfate and tetrathionate and in the net accumulation of elemental sulfur as the final oxidation product, with thiosulfate and tetrathionate acting as a catalytic couple (Fig. 7). Therefore, bacterial tetrathionate formation under sulfidic conditions can account very well for the accumulation of elemental sulfur (but not tetrathionate) in natural marine sediments as presented in the reaction scheme of the 'tetrathionate cycle'. In the naturally alkaline marine environment tetrathionate also may be hydrolyzed chemically or enzymatically to form elemental sulfur, thiosulfate and sulfate (Roy \& Trudinger 1970). Although the accumulation of large amounts of elemental sulfur has been observed in several basin sediments of the Baltic Sea during the past years (e.g. Fig. 5, Podgorsek 1998), at present we cannot give any quantitative estimation of the proportion of the elemental sulfur that has passed through the tetrathionate pool. 
Acknowledgements. This work was supported by Grant No. OF0123 from the Federal Ministry of Education, Research and Technology (BMBF) of Germany and was part of the interdisciplinary project on the dynamics in sulfide and methane biotopes of the Baltic and North Sea (DYSMON). Performance of part of the chemical sulfur analyses by A. Schneider is gratefully acknowledged.

\section{LITERATURE CITED}

Bak F, Pfennig N (1987) Chemolithotrophic growth of Desulfovibrio sulfodismutans sp.nov. by disproportionation of inorganic sulfur compounds. Arch Microbiol 147:184-189

Barrett EL, Clark MA (1987) Tetrathionate reduction and production of hydrogen sulfide from thiosulfate. Microbiol Rev 51:192-205

Canfield DE, Thamdrup B (1996) Fate of elemental sulfur in an intertidal sediment. FEMS Microbiol Ecol 19:95-103

Chan CW, Suzuki I (1993) Quantitative extraction and determination of elemental sulfur and stoichiometric oxidation of sulfide to elemental sulfur by Thiobacillus thiooxidans. Can J Microbiol 39:1166-1168

Durand P, Benyagoub A, Prieur D (1994) Numerical taxonomy of heterotrophic sulfur-oxidizing bacteria isolated from southwestern Pacific hydrothermal vents. Can J Microbiol 40:690-697

Ehrlich HL (1990) Geomicrobiology, 2nd edn Dekker M Inc, New York, p 449-513

Fitz RM, Cypionka H (1990) Formation of thiosulfate and trithionate during sulfite reduction by washed cells of Desulfovibrio desulfuricans. Arch Microbiol 154:400-406

Hansen TA (1974) Sulfide als Electronendonor voor Rhodospirillaceae. Proefschrift, University of Groningen

Henneke E, Luther GW, de Lange GJ, Hoefs J (1997) Sulphur speciation in anoxic hypersaline sediments from the eastern Mediterranean Sea. Geochim Cosmochim Acta 61: 307-321

Hollemann AF, Wiberg E (1971) Lehrbuch der anorganischen Chemie. De Gruyter \& Co, Berlin

Imhoff JF (1988) Anoxygenic phototrophic bacteria. In: Austin $B$ (ed) Methods in aquatic bacteriology. Wiley, Chichester, p 207-240

Imhoff JF (1996) Variations of the sulfur cycle in marine environments. In: Fischer E, Grieshaber MK (eds) Processes and structures in marine methane and sulfide biotopes. Shaker, Aachen, p 82-83

Imhoff JF, Schneider A, Podgorsek L (1995) Correlation of viable cell counts, metabolic activity of sulphur-oxidizing bacteria and chemical parameters of marine sediments. Helgol Meeresunters 49:223-236

Jorgensen BB (1988) Ecology of the sulfur cycle: oxidative pathways in sediments. In: Cole JA, Ferguson SJ (eds) The nitrogen and sulfur cycles. Symp Soc Gen Microbiol 42 $3 i-53$

Jørgensen BB (1990) A thiosulfate shunt in the sulfur cycle of marine sediments. Science 249:152-154

Jørgensen BB, Bak F (1991) Pathways and microbiology of thiosulfate transformations and sulfate reduction in a marine sediment (Kattegat, Denmark). Appl Environ Microbiol 57:847-856

Katayama Y, Hiraishi A, Kuraishi H (1995) Paracoccus thiocyanatus sp. nov., a new species of thiocyanate-utilizing facultative chemolithotroph, and transfer of Thiobacillus versutus to the genus Paracoccus as Paracoccus versutus comb. nov. with emendation of the genus. Microbiology $141: 1469-1477$
Kelly DP (1988) Oxidation of sulfur compounds. In: Cole JA, Ferguson SJ (eds) The nitrogen and sulfur cycles. Symp Soc Gen Microbiol 42:65-98

Kuenen JG, Robertson LA, Touvinen OH (1992) The genera Thiobacillus, Thiomicrospira, and Thiosphaera. In: Balows A, Trüper HG, Dworkin M. Harder W. Schleifer KH (eds) The prokaryotes, 2nd edn. Springer, Berlin, p 2638-2657

Lu WP, Kelly DP (1988) Kinetic and energetic aspects of inorganic sulfur compound oxidation by Thiobacillus tepidarjus. J Gen Microbiol 134:865-872

Luther GW, Church TM, Scudlark JR, Cosman M (1986) Inorganic and organic sulfur cycling in salt-marsh pore waters. Science 232:746-748

Mason J, Kelly DP (1988) Thiosulfate oxidation by obligately heterotrophic bacteria. Microbiol Ecol 15:123-134

Neutzling O, Pfleiderer C, Trüper HG (1985) Dissimilatory sulfur metabolism in phototrophic 'non-sulphur' bacteria. J Gen Microbiol 131:791-798

Pachmayr F (1960) Vorkommen und Bestimmung von Schwefelverbindungen in Mineralwasser. $\mathrm{PhD}$ thesis, University of Munich

Piker L, Schmaljohann R, Imhoff JF (1998) Dissimilatory sulfate reduction and methane production in Gotiand Deep sediments (Baltic Sea) during a transition period from oxic to anoxic bottom water (1993-1996). Aquat Microb Ecol 14:183-193

Podgorsek L (1998) Oxidative Prozesse des Schwefelzyklus in den Sedimenten der Ostsee. Aerobe, bakterielle Umsetzungen von Thiosulfat. $\mathrm{PhD}$ thesis, University of Kiel

Roy AB, Trudinger PA (1970) The biochemistry of inorganic compounds of sulfur. Cambridge University Press, Cambridge

Sass $\mathrm{H}$, Steuber J, Kroder M, Kroneck PMH, Cypionka H (1992) Formation of thionates by freshwater and marine strains of sulfate-reducing bacteria. Arch Microbiol 158: $418-421$

Sorokin DY (1992) Catenococcus thiocyclus gen. nov. sp. nov. - a new facultatively anaerobic bacterium from a nearshore sulphidic hydrothermal area. J Gen Microbiol 138: 2287-2292

Sorokin DY (1993) Oxidation of thiosulfate to tetrathionate by the marine pseudomonad $\mathrm{ChG} 7-3$; effects on growth and characterization of the oxidation system. Microbiologiya 62:223-230

Sorokin DY (1996) Oxidation of sulfide and elemental sulfur to tetrathionate by chemoorganoheterotrophic bacteria. Microbiology 65:5-9

Sorokin DY, Robertson LA, Kuenen JG (1996) Sulfur cycling in Catenococcus thiocyclus. FEMS Microbiol Ecol 19: $117-125$

Steudel R, Holdt G, Göbel T, Hazeu W (1987) Chromatographic seperation of higher polythionates $\mathrm{S}_{\mathrm{n}} \mathrm{O}_{6}{ }^{2-}(\mathrm{n}=$ 3...22) and their detection in cultures of Thiobacillus ferrooxidans; molecular composition of bacterial sulfur excretinns. Angew Chern 99:143-146

Thamdrup B, Finster K, Hansen JW, Bak F (1993) Bacterial disproportionation of elemental sulfur coupled to chemical reduction of iron or manganese. Appl Environ Microbiol 59:101-108

Thiemann B, Imhoff JF (1996) Differentiation of Ectothiorhodospiraceae based on their fatty acid composition. Syst Appl Microbiol 19:223-230

Trüper HG (1975) The enzymology of sulfur metabolism in phototrophic bacteria - a review. Plant Soil 43:29-39

Tuttle $\mathrm{JH}_{1}$ Jannasch HW (1973) Sulfide and thiosulfate-oxidizing bacteria in anoxic marine basins. Mar Biol 20: $64-70$ 
Tuttle JH, Holmes PE, Jannasch HW (1974) Growth rate stimulation of marine pseudomonads by thiosulfate. Arch Microbiol 99:1-14

Vedenina IY, Sorokin DY (1993) ATP synthesis by heterotrophic bacteria on oxidation of thiosulfate to tetrathionate. Microbiologiya 61:764-769

Wentzien S, Sand W. Albertsen A, Steudel R (1994) Thiosulfate and tetrathionate degradation as well as biofilm generation by Thiobacillus intermedius and Paracoccus versu-

Editorial responsibility: Tom Fenchel,

Helsingør, Denmark tus studied by micro-calometry, HPLC, and ion-pair chromatography. Arch Microbiol 161:116-125

Widdel F (1988) Microbiology and ecology of sulfate- and sulfur-reducing bacteria. In: Zehnder A.JB (ed) Biology of anaerobic microorganisms. Wiley \& Sons, New York, p 469-587

Wood AP, Kelly DP (1986) Chemolithotrophic metabolism of the newly isolated moderately thermophilic, obligately autotrophic Thiobacillus tepidarius. Arch Microbiol 144:71-77

Submitted: February 2, 1998; Accepted: November 2, 1998 Proofs received from author(s): June 1, 1999 